\title{
DIREKTIVA O USKLAĐIVANJU PRAVA DRŽAVA ČLANICA EUROPSKE UNIJE U VEZI SA SAMOZAPOSLENIM TRGOVAČKIM ZASTUPNICIMA
}

\author{
UDK: 347.732 (4-6 EU) \\ DOI: $10.31141 /$ zrpfs.2020.57.138.1035 \\ Pregledni znanstveni rad \\ Primljeno: 15. svibnja 2020.
}

\begin{abstract}
Direktiva o usklađivanju prava država članica Europske unije u vezi sa samozaposlenim trgovačkim zastupnicima stupila je na snagu 1986. godine s ciljem usklađivanja zakonodavstava država članica EU-a oko ugovora između samozaposlenih trgovačkih zastupnika. Direktiva usklađuje: prava i obveze trgovačkih zastupnika i njihovih nalogodavaca, naknade trgovačkim zastupnicima te osobito odštete ili naknade trgovačkim zastupnicima nakon završetka ugovora. Ciljevi su Direktive zaštita trgovačkih zastupnika, poboljšavanje uvjeta tržišnog natjecanja unutar Europske unije, povećanje sigurnosti trgovačkih poslova te uredno poslovanje na zajedničkom tržištu. Europska komisija je u sklopu programa REFIT 2012. godine ocijenila Direktivu kao uspješnu i učinkovitu, što je važno budući da je djelatnošću trgovačkih zastupnika ostvareno 3 posto trgovinskog prometa u Uniji. ${ }^{1}$
\end{abstract}

Ključne riječi: Direktiva o samozaposlenim trgovačkim zastupnicima, Europsko pravo, Trgovačko pravo

\section{UVOD}

Europska unija donijela je Direktivu o usklađivanju prava država članica EU-a u vezi sa samozaposlenim trgovačkim zastupnicima (86/653/EEZ) (nadalje: Direktiva) kako bi uskladila nacionalna zakonodavstva država članica kojima se reguliraju ugovori između samozaposlenih trgovačkih zastupnika i njihovih nalogodavaca. Budući da se radi o harmonizaciji putem Direktiva, svaka pojedina zemlja mogla je odabrati način kako će implementirati propise ove Direktive u svoje zakonodavstvo. ${ }^{2}$ Upravo se zato razlikuju propisi pojedinih zemalja članica EU-a u opsegu zaštite zastupnika. Tako je na primjer u Njemačkoj u Trgovačkom zakoniku (Handelsgesetzbuch - HGB) proširena primjena Direktive na sve vrste zastupnika, dok je hrvatsko zakonodavstvo primijenilo Direktivu samo u reguliranju ugovora o trgovačkom zastupanju u Zakonu o obveznim odnosima. Njemačko zakonodavstvo bilo je značajan izvor i inspiracija pri donošenju Direktive, jer se

\footnotetext{
1 Podaci za 2012. godinu.

2 Ugovor o funkcioniranju Europske unije, čl. 288., CELEX br. 12016E288.
} 
u njemačko zakonodavstvo vrlo rano počela uvoditi zaštita trgovačkih zastupnika, koji se smatraju slabijom ugovornom stranom u ugovorima između trgovačkih zastupnika i nalogodavaca.

Povijesno gledano, države članice EU-a imale su različita pravila o pravima i obvezama trgovačkih zastupnika i njihovih nalogodavaca, što je stvaralo pravnu neizvjesnost i otežavalo poslovanje unutar Europske unije. Stoga je opći cilj Direktive, donesene 1986. godine, stvaranje jedinstvenog tržišta za trgovačko zastupanje i uklanjanje prekograničnih aktivnosti trgovačkih zastupnika i njihovih nalogodavaca.

Osim zaštite trgovačkih zastupnika kao slabije ugovorne strane, razlozi donošenja bili su poboljšavanje uvjeta tržišnog natjecanja unutar Europske unije, povećanje sigurnosti trgovačkih poslova, te uredno poslovanje na zajedničkom tržištu.

Važno je napomenuti da je, usprkos činjenici da je Direktiva donesena 1986. godine, i dalje izrazito aktualno pitanje u Europskoj uniji. Europska komisija je u prosincu 2012. u svom programu REFIT, ${ }^{3}$ koji je uspostavljen radi učinkovitijeg provođenja europskog zakonodavstva, preispitala i Direktivu o usklađivanju prava država članica u vezi sa samozaposlenim trgovačkim zastupnicima. Ocijenjeno je da je u 2012. godini djelovalo oko 590.000 trgovačkih zastupnika u Europskoj uniji, čijom je djelatnošću ostvareno 260 milijardi eura prometa, što je oko $3 \%$ ukupnog trgovinskog prometa. Nalogodavaca je u Europskoj uniji 1,7 milijuna, od čega su $88 \%$ mala i srednja poduzeća. ${ }^{4}$

\section{CILJEVI DIREKTIVE}

Direktiva Vijeća o usklađivanju prava država članica u vezi sa samozaposlenim trgovačkim zastupnicima ima nekoliko ciljeva. S jedne strane, Direktiva je osmišljena da bi se smanjile distorzije i narušavanje tržišnog natjecanja te da bi se mogla izgraditi trgovinska praksa trgovačkih zastupnika. ${ }^{5} \mathrm{~S}$ druge strane, jedan od glavnih ciljeva Direktive jest zaštita trgovačkih zastupnika od njihovih nalogodavaca.

Jedan od razloga za donošenje Direktive bila je značajna razlika u nacionalnim pravima država članica, što utječe na uvjete tržišnog natjecanja i zastupanja u Uniji. Važno je stoga paziti na sigurnost trgovačkih poslova, jer te razlike mogu značajno spriječiti sklapanje i izvršavanje ugovora o trgovačkom zastupanju u kojima nalogodavac i trgovački zastupnici imaju poslovni nastan u različitim državama članicama.

Uvjeti robne trgovine između država članica trebali bi biti slični uvjetima na jedinstvenom tržištu, što iziskuje usklađivanje pravnih sustava država članica do

3 Regulatory Fitness and Performance Programme.

${ }_{4}$ https://ec.europa.eu/docsroom/documents/11482/attachments/2/translations/en/renditions/native

5 Gebauer, Martin, Christoph Teichmann and Christian Baldu, Europäisches Privat- Und Unternehmensrecht, Mayer, Justus; poglavlje 5.: Handelsvertreterrecht, 1. izdanje, Baden-Baden: Nomos, 2016., str. 445. 
mjere koja osigurava uredno djelovanje zajedničkog tržišta. Budući da je zajedničko tržište jedna od četiri temeljne slobode Europske unije i s obzirom da kolizijska pravila, čak i da su jednoobrazna, ne bi mogla ukloniti nedosljednosti u području trgovačkog zastupanja, bilo je potrebno uskladiti prava država članica u tom pogledu.

Stoga je osnovni cilj Direktive puna harmonizacija nacionalnih zakonodavstava na način da države članice odrede opseg i načine ujednačavanja pojedinačnih propisa i pravila. ${ }^{6}$

Iako je cilj jednak, modaliteti ujednačavanja razlikuju se od države do države, ponajviše u pogledu plaćanja trgovačkom zastupniku. Njemački model pretpostavlja da zastupnik nije nužno u potpunosti kompenziran za svoj rad u trenutku prestanka ugovora. ${ }^{7}$ Polazi se od činjenice da ce nalogodavac nastaviti dobivati koristi iz poslovnih odnosa koje je pribavio trgovački zastupnik, dok trgovački zastupnik nakon prestanka ugovora prestaje dobivati proviziju za dogovorene poslove. ${ }^{8}$ Francusko pravo, kao jedno od predvodnika drugog modaliteta zaštite trgovačkog zastupnika, predviđa model kompenzacije za prestanak ugovora te se razlikuje od njemačkog modela utoliko što trgovački zastupnik ne treba dokazivati da je pretrpio gubitak.

Neke situacije koje nisu regulirane pokazuju da Direktiva ne propisuje konačna pravila, nego daje slobodu državama članicama da same odrede koji su dodaci potrebni. Bilo je važno uspostaviti brojne kogentne propise, jer je u privatnom sektoru sloboda sastavljanja ugovora osobito tipična za uzajamno poduzetništvo te stoga prilično problematična za reguliranje. ${ }^{9}$ Direktiva ima široku međunarodnu, ali i nacionalnu primjenu. Primjenjuje se ne samo na međunarodne (cross-border) trgovinske sporazume, nego i na nacionalne predmete u državama članicama. ${ }^{10}$

\section{SADRŽAJ I DEFINICIJE DIREKTIVE O USKLAĐIVANJU PRAVA DRŽAVA ČLANICA U VEZI SA SAMOZAPOSLENIM TRGOVAČKIM ZASTUPNICIMA}

\subsection{Tko je zastupnik?}

U članku 1. Direktive propisano je područje primjene Direktive koje se odnosi na ,zakone i druge propise koji uređuju odnose između trgovačkih zastupnika i njihovih nalogodavaca“. Pojam trgovačkog zastupnika definiran je i pozitivno i

6 Westphal, Bernd, Die Handelsvertreterrichtlinie Und deren Umsetzung in den Mitgliedstaaten der Europäischen Union, Münster, Univ., Dissertation, 1994., str. 58.

7 Kordiš, Hrvoje, „Posebna naknada trgovačkom zastupniku“, Pravo i porezi, br. 1/12: siječanj 2012., str. 38 .

8 Hopt, Klaus J., Handelsvertreterrecht: $\$ 84$ - 92c, HGB; Mit Materialien 5., München: Beck, 2015., str. 133 .

9 Schmidt, Karsten. Handelsrecht, 6. izdanje, Köln: Heymann, 2014., str. 865.

10 Vidi presudu Europskog suda Centrosteel, ECLI:EU:C:2000:137, https://eur-lex.europa.eu/legalcontent/EN/TXT/?uri=CELEX:61998CC0456, točka 13. 
negativno. Trgovački zastupnik je, prema čl. 1. st. 2., samozaposleni posrednik koji ima stalno ovlaštenje za posredovanje pri prodaji ili kupnji robe $u$ ime druge osobe (nalogodavca), odnosno za posredovanje i sklapanje takvog posla u ime i za račun nalogodavca.

Osoba koja može imati svojstvo nalogodavca ne definira se izravno, nego kao trgovački zastupnik pa možebitno svojstvo nalogodavca kao prodavatelja ili poduzetnika nije važno. Nadalje čl. 1. st. 3. određuje da trgovački zastupnik u smislu ove Direktive ne može biti osoba koja ima svojstvo službene osobe te je kao takva ovlaštena za neko trgovačko društvoili udrugu preuzimati obveze, zatim partner koji je zakonski ovlašten za druge partnere preuzimati obveze te također stečajni upravitelj, stečajni upravitelj s ovlaštenjem poslovođe, likvidacijski ili stečajni upravitelj. Također je propisano da se Direktiva ne primjenjuje na trgovačke zastupnike koji za svoju djelatnost nisu plaćeni ili one koji posluju na burzama tj. robnim tržištima te na tijelo i podružnice s nazivom „Kraljevski zastupnici za prekomorske vlade i uprave“ koje su osnovane 1797. godine u Ujedinjenom Kraljevstvu. Važno je reći da se sve značajke definicija, kao i druge odredbe Direktive, trebaju tumačiti samostalno te da su također podložne tumačenju Europskog suda pravde (nadalje Europski sud), koji također može prihvatiti pitanja koja su izvan područja primjene Direktive, pod uvjetom da se radi o definicijama koje proizlaze iz Direktive. ${ }^{11}$

U praksi se često izraz „zastupnik“ koristi za različite vrste osoba te je stoga potrebno razlikovati o kakvoj se vrsti zastupanja u konkretnom slučaju radi. ${ }^{12}$ Budući da se pojam zastupnika može tumačiti kao svaki oblik zastupanja interesa druge osobe, hrvatski Zakon o obveznim odnosima (nadalje ZOO) u svojim propisima definira zastupnika definicijom samog ugovora o trgovačkom zastupanju. Kod trgovačkog zastupanja radi se isključivo o ekonomskim interesima prodaje robe putem druge osobe. ${ }^{13}$ Dvije su osnovne mogućnosti kod ugovaranja: 1.) pregovaranje o sklapanju ugovora u ime i za račun nalogodavca ili 2.) ako je uz pregovaranje ugovoreno i sklapanje ugovora s trećim osobama u ime i za račun nalogodavca od strane zastupnika. ${ }^{14}$ Budući da je hrvatsko pravo usklađeno s Direktivom, zakonodavstvo se ne razlikuje previše od zakonodavstava ostalih država članica. Međutim, značajne su razlike u pravima država članica s obzirom na nazive, vrste i ovlasti zastupnika.

Komparativnom analizom čl. 803. ZOO-a može se vidjeti da hrvatskom pojmu trgovačkog zastupnika odgovara njemački pojam Handelsvertreter, koji je definiran u njemačkom trgovačkom zakoniku (Handelsgesetzbuch-HGB) u \$84. Trgovački zastupnik u njemačkom pravu definira se kao samostalni trgovac kojemu je stalno

11 Vidi presude Europskog suda Poseidon Catering, BV, https://eur-lex.europa.eu/legal-content/EN/ TXT/?uri=CELEX:62004CJ0003, točka 14.-17. te Volvo Car Germany, https://eur-lex.europa.eu/legalcontent/EN/TXT/?uri=CELEX:62009CC0203, točka 23.-25.

12 Čuveljak, Jelena, „Ugovor o komisiji i ugovor o trgovinskom zastupanju“, Pravo i porezi, br. 7. srpanj 2008., str. 32.-42.

13 Mlikotin-Tomić, Daša, „Ugovor o trgovačkom zastupanju“, Pravo i porezi, br. 3., ožujak 2002., str. 12.-18.

14 Čl. 804., st. 1. ZOO-a. 
povjereno da posreduje ili sklapa poslove u ime nalogodavca (njem. Unternehmer/ Prinzipal).

U njemačkom se pravu općenito osobe, kojima trgovac može povjeriti obavljanje poslova, dijele na samostalne i nesamostalne osobe (Hilfspersonen). ${ }^{15}$ Nesamostalne su osobe (Handlungsgehilfe) one koje rade u podređenom položaju s utvrđenom naknadom-plaćom, što bi u hrvatskom odgovaralo pojmu trgovačkog predstavnika. ${ }^{16}$ Samostalne osobe mogu sklapati poslove u ime trgovca ili u svoje osobno ime. Osobe koje sklapaju poslove u tuđe ime ili samo posreduju su Handelsvertreter (§§84-92c HGB) i Handelsmakler (\$93-104 HGB). Handelsmakler je osoba kojoj, za razliku od Handelsvertreter (trgovačkog zastupnika), nije povjereno stalno posredovanje te pri posredovanju u sklapanju ugovora mora imati u vidu interese svih stranaka, što donekle odgovara hrvatskom pojmu posrednika. Osobe koje poduzimaju poslove u svoje ime, ali za tuđi račun su Kommisionar, Spediteur, Lagerhalter i Frachtführer. Kommisionar se od trgovačkog zastupnika u njemačkom pravu, kao i u hrvatskom, razlikuje po tome što nema obilježje samostalnosti i što sklapa poslove u svoje ime, ali za tuđi račun (račun nalogodavca). ${ }^{17}$

\subsection{Samostalnost}

Obilježja samostalnosti razlikuju trgovačkog zastupnika od prodajnih predstavnika i drugih vrsta zastupnika koji su ovisniji o nalogodavcu. ${ }^{18}$ Europski sud je, među ostalim, kao značajke samostalnosti odredio i slobodu djelovanja i određivanja radnog vremena. ${ }^{19}$ Zanimljivo je da, kao što je već rečeno, ZOO pri definiranju ne određuje pojam trgovačkog zastupnika, nego to čini u definiciji ugovora o trgovinskom zastupanju ${ }^{20}$ te ne spominje obilježja samostalnosti djelovanja trgovačkog zastupnika, kao što je to slučaj u njemačkom HGB-u. Štoviše, u članku 813. propisuje se dužnost postupanja po uputama nalogodavca pri vođenju pregovora i sklapanju ugovora. Nasuprot tomu, u definiciji trgovačkog zastupnika prema njemačkom HGB-u samostalnost je naglašena kao bitna karakteristika, ${ }^{21}$ jer se trgovačkim zastupnikom smatra osoba koja samostalno posreduje i/ili sklapa poslove za nalogodavca. Osoba kojoj je povjereno posredovanje i/ili sklapanje poslova, ali bez obilježja samostalnosti, smatra se zaposlenikom. ${ }^{22}$

15 Alpmann, Josef A. Handelsrecht.16. Aufl. Münster: Alpmann und Schmidt, 2016., str. 61.

16 Mlikotin-Tomić, Daša, „Ugovor o trgovačkom zastupanju“, Pravo i porezi, br. 3., ožujak 2002., str. 14

17 Vidi usporedno §383. HGB-a i čl. 785. ZOO-a.

18 Hopt, Klaus, Neue Selbständigkeit und Scheinselbständigkeit, Festschrift Für Dieter Medicus: Zum 70. Geburtstag; Beuthien, Volker, and Dieter Medicus,Köln: Heymann, 1999., str. 235.

19 Presuda Blanckaert und Williems, EU:C:1981:70, https://eur-lex.europa.eu/legal-content/EN/ TXT/?uri=CELEX\%3A61980CJ0139, t. 13.

20 Vidi ZOO, čl. 804., st. 1.

21 Vidi HGB, §84.

22 Vidi HGB, §84., ab.1. i 2. 
U državama članicama EU-a može se propisati kriterij slobodnog djelovanja i slobodnog određivanja radnog vremena, ali i ne mora. Pri definiranju osobe trgovačkog zastupnika mogu se primijeniti i ostali kriteriji, kao što su na primjer struktura naplate, neovisnost organizacije pri kojoj djeluje trgovački zastupnik itd. ${ }^{23}$ Direktiva u čl. 2. st. 2. daje slobodu državama članicama da se Direktiva ne primjenjuje na osobe koje de facto obavljaju djelatnost trgovačkog zastupnika, ako se ta djelatnost smatra sekundarnom. Sekundarnom bi se primjerice mogla smatrati djelatnost trgovačkog zastupnika sa skraćenim radnim vremenom.

\subsection{Stalno ovlaštenje}

Kod definiranja „stalnog ovlaštenja za posredovanje“ važno je da se radi o posredovanju na određeno vrijeme. Europski je sud definirao da je moguće primijeniti Direktivu u slučaju kada je ugovor o trgovačkom zastupanju sklopljen na određeno vrijeme od godine dana, ako je trgovački zastupnik ovlašten pregovarati o produljenju ugovora. ${ }^{24}$

Iako u hrvatskoj definiciji ugovora o trgovačkom zastupanju nije izrijekom spomenuta trajnost ugovora, to proizlazi iz teksta čl. 804. st. 1. u kojem se rabi formulacija „za vrijeme trajanja ugovora“. Njemački HGB u §84 određuje da trgovačkom zastupniku treba biti povjereno trajno djelovanje. ${ }^{25}$

Direktiva uključuje djelatnosti posredovanja te djelatnosti posredovanja i sklapanja poslova u ime i za račun nalogodavca. Posredovanje je moguće definirati kao napor trgovačkog zastupnika da se postigne sklapanje ugovora između nalogodavca i treće osobe te pritom nije potrebno prisustvo trgovačkog zastupnika pri daljnjim pregovorima. Ako je trgovački zastupnik ovlašten sklopiti ugovor, ugovor se uvijek sklapa u ime i za račun nalogodavca. Pojedine države članice odredile su pri implementaciji Direktive šire područje važenja, pa se tako, na primjer, u njemačkom pravnom sustavu Direktiva primjenjuje i na posrednike. ${ }^{26}$ Ipak, Direktiva propisuje primjenu na posredovanje pri prodaji/kupnji robe ili posredovanje u sklapanju takvog posla u ime i za račun nalogodavca. To znači da ugovori o posredovanju pri kupnji/prodaji nekretnina, pružanju usluga, licencija i sl., nisu izričito obuhvaćeni Direktivom, ali postoji mogućnost država članica da primijene odredbe Direktive i na te ugovore. Hrvatsko zakonodavstvo je pri definiranju mogućih nalogoprimaca, kao što su komisionari, posrednici, distributeri itd. i njihovih ovlasti restriktivno odredilo primjenu Direktive samo na djelatnosti trgovačkog zastupnika. Većina država članica proširila je propise Direktive i na druge slične ugovore, pa su u nekim slučajevima obuhvaćena posredovanja u

\footnotetext{
23 Grundmann, Stefan. Europäisches Schuldvertragsrecht: Das Europäische Recht Der Unternehmensgeschäfte, Berlin: de Gruyter, 1999., str. 380.

${ }^{24}$ Presuda Europskog suda Poseidon Catering BV, op.cit. u bilj. 10, točka 26.

25 Bilić, Antun, „Pravni učinci posrednikove interesne isprepletenosti“, Pravo u gospodarstvu, godište 51., svezak 2, ožujak 2012., Zagreb, Hrvatski savez udruga pravnika u gospodarstvu, str. 633.

26 Mayer, J., op. cit. u bilj. 4, str. 447.
} 
drugim prodajnim ili uslužnim transakcijama ili čak posredovanje kod svih vrsta ugovora i transakcija. ${ }^{27}$

\subsection{Obveze ugovornih stranaka}

U drugom poglavlju Direktive reguliraju se prava i obveze stranaka, odnosno trgovačkog zastupnika i njegova nalogodavca. Obveze su kogentne naravi, kako propisuje čl. 5. Direktive: „Stranke ne mogu odstupati od odredbi čl. 3. i 4. ove Direktive."

\subsubsection{Obveze trgovačkog zastupnika}

Primarna je obveza trgovačkog zastupnika, propisana u čl. 3. st. 1., pridržavanje generalne klauzule načela dobre vjere i poštenja, koja se detaljnije razrađuje u drugom stavku istoga članka trima specijalnim klauzulama. Načelo dobre vjere i poštenja ukorijenjeno je u europskom kontinentalnom pravu, kako građanskom tako i trgovačkom, te se smatra općim, unatoč svim tradicionalnim razlikama među zakonodavstvima država članica, ${ }^{28}$ pa je načelo uključeno u Direktivu. Europski sud do sada nije točnije definirao načelo dobre vjere i povjerenja. ${ }^{29}$

Nasuprot tome, dužnost zaštite interesa stranke dopunjena je novom općom klauzulom, u kojoj je interes stranke u središtu: „Trgovački zastupnik mora u obavljanju svojih djelatnosti brinuti o interesima nalogodavca...".30 Međutim, Europski sud dosada nije konkretizirao ni ove pojmove kroz sudsku praksu. Smatra se da se obveza brige za interese nalogodavca i pridržavanja načela dobre vjere i poštenja, odnosi na cjelokupnu djelatnost trgovačkog zastupnika, čak i nakon završetka ugovora. ${ }^{31}$

Dužnosti trgovačkog zastupnika pobliže se određuju u st. 2., ali i u pravnim terminima koji daju mjesta širokoj interpretaciji, pa je tako na primjer propisana obveza trgovačkog zastupnika da uloži odgovarajući trud radi posredovanja i sklapanja ugovora, međutim nije pobliže obrazloženo kako se treba ocjenjivati trud i zalaganje trgovačkog zastupnika.

Također, trgovački zastupnik mora nalogodavcu dostaviti sve potrebne podatke koji su mu dostupni, što uključuje prije svega informacije potrebne za sklapanje ugovora, izvršavanje transakcija i konačan račun. ${ }^{32}$ Osim toga, trgovački zastupnik

27 Mayer, J., op. cit. u bilj. 4, str. 447; tako čine Njemačka, Austrija, Nizozemska, Belgija, Italija, Španjolska, Portugal i Bugarska.

28 Mayer, J., op. cit. u bilj. 4, str. 450.

29 Mayer, J., op. cit. u bilj. 4, str. 450.

30 Čl. 3. st. 1. Direktive.

31 Riesenhuber, Karl, System und Prinzipien des Europäischen Vertragsrechts, Berlin:de Gruyter, 2003., str. 358.

32 Detaljnije propisano Direktivom o uslugama na unutarnjem tržištu 2006/123/EZ, CELEX: 32006L0123, https://eur-lex.europa.eu/legal-content/HR/TXT/?qid=1549639115137\&uri=CELEX:3200 6L0123, čl. 22. 
dužan je na zahtjev principala dostaviti podatke o trenutnim djelatnostima posredovanja i tržištu na kojem djeluje. ${ }^{33}$ Naposljetku, propisana je obveza slijeđenja razumnih uputa nalogodavca.

Budući da su obveze trgovačkog zastupnika propisane širokim općim klauzulama te nisu preciznije konkretizirane, ostavlja se državama članicama da ih detaljnije reguliraju te dopune, pri čemu detaljnija regulacija mora biti u granicama navedenog članka. ${ }^{34}$ Tako na primjer države članice mogu uvesti pravila o povjerljivosti ili zabrani natjecanja tijekom ugovora. Hrvatski zakonodavac propisao je tako na primjer dužnost redovitog obavještavanja nalogodavca o ispunjenju svojih ugovornih obveza, o trećim osobama koje su spremne pregovarati ili sklopiti posao te o ugovorima koje je sklopio u ime i za račun nalogodavca. ${ }^{35} \mathrm{U}$ ZOO-u također je propisana obveza čuvanja tajni ${ }^{36}$ te vraćanja stvari danih na uporabu. ${ }^{37}$ Ako trgovački zastupnik u tome posebno jamči za ispunjenje ugovora, ${ }^{38}$ nacrt Direktive također je sadržavao odredbu o tzv. delkredere proviziji na koju posljedično trgovački zastupnik ima pravo. Odredbe čl. 5. ne sprečavaju ugovorne strane da detaljnije konkretiziraju pojedine ugovorne obveze ili da ugovore daljnje obveze trgovačkog zastupnika. ${ }^{39}$

U čl. 816. ZOO-a propisuje se posebna odgovornost trgovačkog zastupnika. U slučaju kad trgovački zastupnik posebno pisano jamči ispunjenje obveze iz ugovora, koji je sklopio između nalogodavca i treće osobe ili čijemu je sklapanju posredovao, ima pravo na posebnu proviziju koja se naziva delkredere provizija.

\subsubsection{Obveze nalogodavca}

Obveze nalogodavca propisane se u čl. 4. Direktive. Nalogodavac je, jednako kao i trgovački zastupnik, obvezan postupati u skladu s načelom poštenja i dobre vjere u odnosu s trgovačkim zastupnikom. Detaljnije je propisano da, prema st. 2., nalogodavac mora osigurati trgovačkom agentu neophodnu dokumentaciju vezanu za robu, pribaviti mu podatke neophodne za izvršenje ugovora, te u primjerenom roku obavijestiti trgovačkog zastupnika o mogućem značajnom smanjenju opsega trgovačkih poslova, koje bi trgovački zastupnik uobičajeno mogao očekivati. Također se propisuje obveza nalogodavca da u primjerenom roku izvijesti trgovačkog zastupnika je li posao u kojem je posredovao prihvaćen, odbijen ili nije proveden. I za obveze nalogodavca i moguće ugovaranje detaljnijih i/ili dodatnih obveza vrijedi već rečeno.

Hrvatski ZOO također propisuje sve navedeno te se u čl. 819. izričito navodi obveza nalogodavca na isplatu provizije za ugovore koji su sklopljeni dok traje

\footnotetext{
33 Mayer, J., op. cit. u bilj. 4, str. 450.

Westphal, B., op. cit. u bilj. 5, str. 63. i 66.

Čl. 813 ZOO-a.

Čl. 814 ZOO-a.

Čl. 815 ZOO-a.

Čl. 816 ZOO-a.

Mayer, J., op. cit. u bilj. 4, str. 451.
} 
ugovor o trgovačkom zastupanju koji je sklopljen njegovim posredovanjem, te za ugovore koje je sklopio zastupnik u ime i za račun nalogodavca, kada je za to bio ovlašten. Nadalje se u čl. 819. - 824. ZOO-a detaljno regulira obveza plaćanja provizije u skladu sa smjernicama Direktive.

Obveza plaćanja provizije detaljnije se regulira u trećem poglavlju Direktive te stoga nije uvrštena u primarne obveze u čl. 4. Direktive.

\subsubsection{Obveza plaćanja}

Važna je odrednica ugovora o trgovačkom zastupanju obveza nalogodavca da isplati trgovačkom zastupniku naknadu za trgovački posao. Obveza naknade detaljno je regulirana u trećem poglavlju Direktive (čl. 6. - 12.). Prema čl. 6. st. 1. u nedostatku bilo kakvog sporazuma o naknadi, čak ako države članice nisu propisale obveznu odredbu o visini naknade, trgovački zastupnik ima pravo na naknadu koja je uobičajena za robu koja čini predmet ugovora o zastupanju u mjestu gdje on obavlja svoje djelatnosti. Također se propisuje da ako ne postoji takva trgovačka praksa, trgovački zastupnik ima pravo na razumnu naknadu koja se određuje uzimajući u obzir sve dijelove posla. Drugi oblici naknade (npr. fiksne naknade ili bonusi koji se ne temelje na broju ili vrijednosti posla) nisu propisani Direktivom. ${ }^{40}$ Ako se naknada ili dio izračunava na temelju broja ili vrijednosti posla smatra se provizijom u smislu Direktive. ${ }^{41}$ Provizija je nagrada za posredovanje, obavljeni posao, prodaju, obično u postotku ukupne vrijednosti. ${ }^{42}$ Ako trgovačkom zastupniku nije u cijelosti ili bar djelomično isplaćena provizija, neće se primjenjivati odredbe o proviziji iz Direktive. ${ }^{43}$

Prema čl. 7. države članice obvezne su propisati tri moguća oblika provizije: 1.) provizija za posredovanje ili zaključenje ugovora; 2.) provizija za područje ili klijente te 3.) provizija za naknadno zaključene ugovore. Obveza propisivanja prve dvije provizije određena je kumulativno, pri čemu se većina država članica odlučila za drugi oblik, dok su se za prvi oblik opredijelile Njemačka (\$87/2 HGB), Francuska, Grčka i Danska. ${ }^{44}$ Hrvatska propisuje obveznim prvi oblik provizije, dok se dispozitivno ostavlja mogućnost ugovaranja isključivog prava posredovanja na određenom području ili s određenom skupinom klijenata. ${ }^{45}$

Provizija za posredovanje, odnosno za zaključenje ugovora, smatra se osnovnom vrstom provizije. ${ }^{46}$ Trgovački zastupnik ima pravo na ovu proviziju, ako između njegovih posredničkih usluga i zaključenja konkretnog ugovora između nalogodavca i treće osobe postoji uzročno-posljedična veza. Doduše, ta veza ne treba biti izravna,

40 Mayer, J., op. cit. u bilj. 4, str. 452.

${ }_{41}$ Čl. 6. st. 2. Direktive.

42 Anić, Vladimir, Rječnik hrvatskog jezika, drugo dopunjeno izdanje, Zagreb, 1994., str. 830.

43 Čl. 6. st. 3. Direktive.

44 Mayer, J., op. cit. u bilj. 4, str. 452.

45 Vidi čl. 819. ZOO-a, st. 1., 2., 3.

46 Radović, Mirjana, „Provizija trgovinskog zastupnika“, Anali Pravnog fakulteta u Beogradu: Časopis za pravne i društvene nauke, VOL. 63, br. 1, 2015. 
jer Direktiva u čl. 7. st. 1. propisuje samo da posao treba biti „sklopljen zbog njegovog posredovanja“ ili ,ako je sklopljen s trećom osobom koju je prethodno pridobio kao stranku za sklapanje istovrsnih poslova“. U drugom slučaju radi se o neizravnoj proviziji, zato što je ugovor zaključen samo zbog početnog djelovanja trgovačkog zastupnika, to jest pribavljanja klijenata za zaključenje ugovora. ${ }^{47}$

Ako je trgovačkom zastupniku dodijeljeno područje ili klijenti prema čl. 7. st. 2., trgovački zastupnik može imati pravo na proviziju neovisno o izvršenju ugovorne obveze. Također je bitno da se iznos provizije ne određuje prema sjedištu stranke s kojom se posao sklapa, nego prema mjestu stvarne poslovne aktivnosti. ${ }^{48}$

Trgovački zastupnik ima pravo na proviziju za trgovački posao koji je sklopljen nakon raskida ugovora ako se sklapanje posla prije svega može pripisati njegovoj djelatnosti i razdoblju koji je bilo obuhvaćeno ugovorom i ako je posao sklopljen u primjerenom roku nakon raskida ugovora, odnosno ako je nalog treće osobe stigao do nalogodavca ili trgovačkog zastupnika prije raskida ugovora o zastupanju. ${ }^{49}$

U čl. 9. predviđena je mogućnost podjele provizije između trgovačkih zastupnika, ako je to u konkretnom slučaju opravdano, no Direktiva ne konkretizira detaljnije ni u kojim bi se slučajevima mogla dijeliti provizija između više trgovačkih zastupnika, niti daje daljnje upute kako bi se trebalo ophoditi sa sukobljenim zahtjevima za proviziju više trgovačkih zastupnika. ${ }^{50}$

Pravo na proviziju dospijeva s izvršenjem posredovanog posla. Prema čl. 10. st. 1. provizija dospijeva čim se ostvari jedna od sljedećih okolnosti: 1.) nalogodavac je izvršio posao, ili 2.) nalogodavac je trebao, u skladu sa svojim sporazumom s trećom stranom, izvršiti posao, ili 3.) treća strana je izvršila posao. Prema st. 2. provizija dospijeva na naplatu najkasnije nakon što je treća strana izvršila svoj dio posla, odnosno kada je trebala izvršiti posao ovisno o radnjama nalogodavca. Pravo na proviziju može se ukinuti ako je utvrđeno da se ugovor između nalogodavca i treće strane neće izvršiti iz razloga koji se ne može propisati nalogodavcu. ${ }^{51}$ Tada se provizija koju je trgovački zastupnik već primio, mora vratiti nalogodavcu. ${ }^{52}$

Nadalje, posljednji članak poglavlja o naknadi propisuje pravila o zahtjevu za provizijom. Nalogodavac je obvezan dostaviti trgovačkom zastupniku izvješće o dospjeloj proviziji koje mora sadržavati glavne podatke na temelju kojih je izračunat iznos provizije do posljednjeg dana mjeseca koji slijedi nakon tromjesečja u kojem je provizija dospjela. Trgovački zastupnik, također ima pravo zahtijevati sve podatke koji su dostupni njegovom nalogodavcu i koji su mu potrebni da bi mogao provjeriti iznos provizije koji mu se duguje.

47 Radović, Mirjana, op. cit. u bilj. 45.

48 Presuda Europskog suda Kontogeorgas, ECLI:EU:C:1996:274, https://eur-lex.europa.eu/legalcontent/EN/TXT/?uri=CELEX:61995CC0104, vidi potpoglavlje 7.4 .

49 Čl. 8. Direktive.

50 Mayer, J., op. cit. u bilj. 4, str. 452.

51 Čl. 11. st. 1 Direktive.

52 Čl. 11. st. 2 Direktive. 


\subsection{Sklapanje i raskid ugovora}

Kao što je već rečeno, u Direktivi nisu propisana kogentna pravila za formu sklapanja ugovora. Propisano je međutim da svaka stranka ima pravo od druge stranke zahtijevati potpisanu ispravu, koja uključuje naknadno ugovorene uvjete, te da odricanje od tog prava nije dopušteno. Budući da se ne propisuje zadana forma, svaka država članica ima pravo sama propisati zahtijeva li se pisani oblik za valjanost ugovora. Tako hrvatski ZOO (čl. 806.) zahtijeva pisani oblik, dok se u njemačkom pravu primjerice za valjanost ugovora ne zahtijeva pisana forma.

Osim izloženih odredaba o sklapanju ugovora, poglavlje IV. regulira produženje ugovora na određeno vrijeme te prestanak trajnih ugovora, te u praksi osobito važno pitanje naknade nakon raskida ugovora. Vezano za naknadu nakon raskida ugovora u literaturi se pojavljuju različiti nazivi za tu vrstu naknade, ${ }^{53}$ pa tako primjerice posebna naknada u slučaju prestanka ugovora, terminalna naknada (prema engl. terminal compensation), pravo na odštetu, pravo na naknadu štete itd. Ako je sklopljen ugovor o zastupanju na određeno vrijeme, a stranke nakon isteka razdoblja nastave s izvršavanjem ugovora, smatrat će se da je sklopljen novi ugovor o zastupanju na neodređeno razdoblje. ${ }^{54}$ Za ugovore sklopljene na neodređeno vrijeme Direktiva pretpostavlja pravo bilo koje stranke na raskid ugovora. Rokovi za obavještavanje o raskidu su također propisani te iznose: najmanje mjesec za prvu godinu ugovora, dva mjeseca ako je već započela druga godina ugovora te tri mjeseca za ugovore koji su na snazi dulje od 3 godine. Ukratko, vrijeme za obavještavanje o raskidu produljuje se s trajanjem ugovora te države članice imaju pravo propisati određenije rokove, ${ }^{55}$ ali u svakom slučaju rokovi moraju biti jednaki kako za nalogodavca tako i za trgovačkog zastupnika. ${ }^{56}$ Ako nije ugovoreno drukčije, zadnji dan roka za obavještavanje mora biti zadnji dan kalendarskog mjeseca. ${ }^{57}$ Ostavljena je mogućnost državama članicama da propišu mogućnost raskida ugovora bez otkaznog roka, ako je jedna stranka propustila ispuniti svoje obveze (sve ili dio) ili u slučaju izvanrednih okolnosti. Nema indicija koje bi mogle ukazati na konkretnije značenje navedenih termina te je stoga ostavljeno državama članicama da same definiraju točno značenje, bilo zakonom ili sudskom praksom. ${ }^{58}$ Indirektno je u čl. 17. st. 4. propisano da ugovor prestaje zbog smrti trgovačkog zastupnika. $^{59}$

53 Vidi usporedno Kordiš, ZOO, Direktiva, Ćesić.

54 Čl. 14. Direktive.

55 Čl. 15. st. 3. Direktive.

56 Čl. 15. st. 4. Direktive.

57 Čl. 15. st. 5. Direktive.

58 Mayer, J., op. cit. u bilj. 4, str. 454.

59 Čl. 17. st. 4. Direktive - Pravo na odštetu na način kako je propisano st. 2. ovog članka, tj. na naknadu štete u slučajevima iz st. 3. ovog članka, također nastupa kad ugovor o zastupanju prestaje zbog smrti trgovačkog zastupnika. 


\section{SUSTAV ODŠTETE NAKON RASKIDA UGOVORA}

Članci 17. i 18. reguliraju jedan od važnijih razloga za nastanak Direktive uopće:60 obvezu odštete trgovačkom zastupniku nakon raskida ugovora o zastupanju. Zahtjev za odštetom centralni je dio prava trgovačkog zastupanja, zato što se najviše pravnih pitanja na sudovima pojavljuje vezano upravo uz ovu temu.

Sustavi odšteta prije donošenja Direktive bili su značajno različiti te većina država članica u svojim zakonodavstvima nije predviđala odštetu za okončanje ugovora. ${ }^{61}$ Njemačka je 1953. godine uvela odredbu § 89b HGB, koja je postala model za regulaciju odštete u Direktivi; u Nizozemskoj se također 1977. godine uveo sličan propis. U Francuskoj je, međutim, problematika odštete regulirana na ponešto drugačiji način i to zahtjevom za kompenzaciju koji trgovački zastupnik može podnijeti, ako je ugovor okončan bez njegove krivnje. Francuski model ne propisuje kako se određuje visina kompenzacije, ali u sudskoj praksi prevladalo je rješenje da iznos kompenzacija treba biti jednak prosječnoj godišnjoj proviziji. ${ }^{62}$ Usprkos francuskom i talijanskom modelu zaštite trgovačkog zastupnika, prvotni nacrt Direktive je predviđao njemački model. Poslije je u nacrt uveden i francuski model kao alternativa, da bi se osigurao pristanak na Direktivu. ${ }^{63} \mathrm{U}$ svakom slučaju ne smije se ugovoriti da trgovački zastupnik nema pravo na odštetu ili kompenzaciju prije isteka ugovora. ${ }^{64}$

\subsection{Posebna naknada}

Prema čl. 17. st. 2., trgovački zastupnik ima pravo na odštetu ako je nalogodavcu osigurao nove stranke ili znatno povećao opseg posla s postojećim strankama, tako da nalogodavac nastavlja ostvarivati znatnu korist od poslovanja s takvim strankama te je plaćanje odštete pravično s obzirom na to da su se okolnosti promijenile. Europski sud definirao je u praksi kako će se određivati jesu li ispunjene navedene pretpostavke. ${ }^{65}$ Visina naknade određuje se u tri faze: 1.) promatra se koliko je kvantitativno bila korist nalogodavca koju mu je donio rad trgovačkog zastupnika, 2.) ocjenjuje se bi li naknada štete, s obzirom na to da su se okolnosti promijenile te je izgubljena, bila pravična, te 3 .) izračunava se iznos odštete, koji ne može prelaziti svotu prosječne godišnje provizije posljednjih 5 godina, a ako je ugovorni odnos trajao manje, svotu prosječne godišnje provizije u doba trajanja ugovora.

60 Saenger, Ingo, Der Ausgleichsanspruch des Handelsvertreters: Beispiel für die Fortentwicklung angeglichenen Europäischen Rechts, 1. Aufl., Baden-Baden: Nomos-Verl.-Ges., 2000., str. 9. i nadalje.

61 Westphal, B., op. cit. u bilj. 5., str. 19.

62 Mayer, J., op. cit. u bilj. 4, str. 454.

63 Mayer, J., op. cit. u bilj. 4, str. 454.

64 Čl. 19. Direktive.

65 Presuda Turgay, ECLI:EU:C:2009:195, https://eur-lex.europa.eu/legal-content/EN/TXT/?uri= CELEX:62007CJ0348. 
Europski sud je presudio da okolnost što su prednosti ostvarene za poduzeća koja se nalaze u istoj grupaciji u kojoj je i poduzeće nalogodavac, ne predstavljaju osnovu za posebnu naknadu. ${ }^{66}$

Termin „nove stranke“ također zahtijeva dodatnu konkretizaciju. Pitanje je tko se sve može smatrati novom strankom koju je pribavio trgovački zastupnik svojim zalaganjem. Prvenstveno, novom strankom smatraju se stranke s određenog područja s kojima do tada nalogodavac nije poslovao i koje su spremne povezati se trajno s nalogodavcem, a za početak poslovnog odnosa zaslužan je trgovački zastupnik. Doduše, novim klijentima smatrat će se i stari klijenti s kojima je trgovački zastupnik obnovio odnose.$^{67}$ Europski sud se u presudi Marchon bavio upravo ovim pitanjem. ${ }^{68}$

Budući da se u tekstu Direktive razlikuju postojeći kupci i novi kupci, moglo bi se pretpostaviti da se pod pojmom novih kupaca mogu smatrati samo oni kupci s kojima nalogodavac prije nije imao poslovne odnose. ${ }^{69}$ No, nije jasno propisano može li se karakteristika „novog“ kupca adresirati u vezi s ukupnim asortimanom robe nalogodavca ili samo $\mathrm{s}$ asortimanom roba koji je ugovoren. ${ }^{70}$

Europski sud odlučio je da se Direktivu treba čitati s obzirom na to da joj je cilj zaštita slabije stranke, odnosno zaštita trgovačkog zastupnika. Termin „,novi kupac" stoga se ne smije tumačiti usko. ${ }^{71}$ Radi li se o novom kupcu, procjenjuje se na temelju robe za koju je trgovački zastupnik dobio nalog. ${ }^{72}$ Činjenica da je nalogodavac već imao poslovne odnose s trgovcem za trgovinu druge robe, ne znači da se taj trgovac ne može promatrati kao „novi kupac“ u slučaju da je trgovački zastupnik. Važno je samo da je trgovački zastupnik uspostavio poslovne odnose za trgovinu robom koja je ugovorena u ugovoru o trgovačkom zastupanju. ${ }^{73}$ To vrijedi čak i onda ako je prodavana roba slična u svojoj naravi. ${ }^{74}$

Nadalje, postoji dvojba kako točno kvantificirati „značajnu mjeru“ povećanja opsega posla s postojećim strankama. ${ }^{75} \mathrm{U}$ literaturi prevladava mišljenje da nije potrebno udvostručiti opseg posla, nego ga je dovoljno povećati. ${ }^{76}$ Takvo stajalište

66 Presuda Turgay, op. cit. u bilj. 64.

${ }^{67}$ Kordiš, Hrvoje, „Posebna naknada trgovačkom zastupniku“, Pravo $i$ porezi, br. 2/12: veljača 2012., str. 48.-49.

68 Presuda Marchon, ECLI:EU:C:2008:23, https://eur-lex.europa.eu/legal-content/HR/TXT/?uri= CELEX:62014CC0315.

69 Presuda Marchon, vidi potpoglavlje 7.7., osobito točku 28.

70 Emde, Raimond, Valdini, Daniel, ,Die Handelsvertreterrichtlinie“, Zeitschrift fur Vetriebsrecht,

Heft 1., Genios, 2017., str. 10.

71 Presuda Marchon, t. 33.

72 Presuda Marchon, t. 34.

73 Presuda Marchon, t. 35.

74 Presuda Marchon, t. 36.

75 Emde, Valdini, opt. cit. str. 11

76 Emde, Raimond. Vertriebsrecht: Kommentar; § 84-92c HGB, Handelsvertreterrecht, Vertragshändlerrecht, Franchiserecht.3., neu bearb. Aufl. Berlin [u.a.]: De Gruyter, 2014., str. 1289. 
opravdava činjenica da je zapravo puno teže uvjeriti već postojećeg kupca na povećanje opsega posla, nego ugovoriti prodaju robe potpuno novom kupcu. ${ }^{77}$

U pogledu zahtjeva pravičnosti u čl. 17, st. 2. (a), druga alineja Direktiva zahtijeva da se moguće nastale štete sagledaju sa svih strana, uključujući i ponašanje nakon raskida ugovora. Kod zahtjeva pravičnosti radi se o širokom pravnom standardu koji u svom radu primjenjuju sudovi država članica, dok države članice imaju mogućnost propisati primjenu trgovinskih klauzula, ponajprije klauzulu zabrane konkurencije. Većina država članica nije iskoristila ovu mogućnost, međutim u pogledu propisivanja klauzule zabrane konkurencije i istovremenog prava na izgubljenu proviziju, treba se uzeti u obzir da klauzule povećavaju proviziju. Stoga u slučajevima kada je ugovorena odgovarajuća naknada vezana za klauzulu zabrane natjecanja, posebna se naknada za raskid ugovora također treba izvanredno izračunati. $^{78}$

Važno je da prema Direktivi isplata posebne naknade ne znači gubitak zahtjeva trgovačkog zastupnika na naknadu štete, prema alineji čl. 17. st. 2 (c): Odobrenje ovakve odštete ne sprečava trgovačkog zastupnika da zahtijeva naknadu štete. Stoga pravo na naknadu štete znači da trgovački zastupnik ne može u potpunosti namiriti svoje gubitke iz dobivene posebne naknade. ${ }^{79}$ Nadalje Europski je sud također presudio da gubitak provizije ne znači gubitak prava na posebnu naknadu. ${ }^{80}$

\subsection{Naknada zbog raskida ugovora}

Prema čl. 17. st. 3., trgovački zastupnik ima pravo na naknadu štete koju trpi zbog raskida ugovornog odnosa s nalogodavcem. Smatra se da je takva šteta nastala ako do raskida ugovornih odnosa dođe pod okolnostima: 1.) koje trgovačkom zastupniku uskraćuju proviziju koju bi mu donijelo uredno izvršenje ugovora, koje istovremeno omogućuje nalogodavcu znatnu korist vezanu za djelovanje trgovačkog zastupnika i/ili 2.) koje nisu omogućile trgovačkom zastupniku da amortizira troškove i raskide nastale pri izvršenju ugovora, a koje je savjetovao nalogodavac. Praksa francuskih sudova pokazala je da zahtjev za naknadom štete redovito dovodi do potraživanja veće svote, nego kod zahtjeva za posebnom naknadom. ${ }^{81}$ Zahtjev za naknadom štete ne ovisi o krivnji ili nezakonitom postupanju nalogodavca, jer bi inače trgovački zastupnik bio zakinut u usporedbi s modelom posebne naknade.

Iako je naknada za prestanak ugovora uređena detaljno, kako mogućnosti propisivanja posebne naknade, tako i zahtjevom za naknadom štete, upravo ta dualnost dovodi do manjkavosti uniformizacije europskih standarda. Budući da Direktiva ne daje nikakve naznake na koji način bi se trebala izračunavati naknada, a nekad ni zakonodavstva država članica ne propisuju način i visinu naknade, ostavlja

\footnotetext{
Emde, Valdini, opt. cit. str. 11.

Emde, Raimond, opt. cit., str. 1336.

Presuda Quenon, vidi potpoglavlje 7.7.

${ }^{80}$ Presuda Turgay, vidi potpoglavlje 7.8.

81 Emde, Valdini, opt. cit. str. 11.
} 
se velika diskrecija sudovima u tom dijelu što dovodi do različite kompenzacije. Na primjer, pokazalo se u praksi da talijanski sudovi imaju tendenciju dodjeljivati znatno manju kompenzaciju negoli njemački sudovi. ${ }^{82}$

Također, propisano je da pravo na kompenzaciju nastupa kada ugovor o trgovačkom zastupanju prestaje zbog smrti trgovačkog zastupnika, što znači da se pravo na kompenzaciju može smatrati nasljednim. ${ }^{83}$

Direktiva propisuje objektivni prekluzivni rok od godine dana od dana raskida ugovora za obavještavanje nalogodavca o namjeri ostvarenja njegovog prava na kompenzaciju. Međutim, sagleda li se ovaj propis sa stajališta potencijalnog nasljednika trgovačkog zastupnika, nejasno je kada taj rok počinje teći za nasljednika ${ }^{84}$ Budući da je trenutak raskida ugovora trenutak smrti trgovačkog zastupnika, treba se smatrati da će se taj trenutak uzimati u obzir, međutim moguće je da potencijalni nasljednik tek poslije sazna za smrt ostavitelja. Zbog pravne sigurnosti smatra se optimalnim primijeniti objektivni rok, jer bi u suprotnom nalogodavac trpio moguću neizvjesnost potraživanja. Države članice nisu slobodne regulirati vremensko ograničenje zahtjeva na način drugačiji od ovog.

Direktiva u čl. 18. propisuje tri slučaja kada ne nastaje obveza plaćanja odštete ili naknade štete iz čl. 17.: 1.) ako je nalogodavac raskinuo ugovor zbog propusta trgovačkog zastupnika, a koji bi prema nacionalnom zakonodavstvu opravdalo trenutni raskid ugovora; 2.) ako je trgovački zastupnik raskinuo ugovor, osim ako je takav prestanak opravdan zbog okolnosti koje se mogu pripisati nalogodavcu ili ako se zbog godina, nemoći ili bolesti trgovačkog zastupnika ne može razumno zahtijevati da nastavi s djelatnostima; 3.) ako u sporazumu s nalogodavcem zastupnik ustupi svoja prava i obveze iz ugovora drugoj osobi.

Isključenje posebne naknade zbog propusta trgovačkog zastupnika u hrvatskom se zakonodavstvu propisuje na način da nalogodavac to nije dužan platiti ako je uzrok zastupnikovo skrivljeno ponašanje. ${ }^{85}$ Takva formulacija upućuje na to da je tada nalogodavac dužan dokazati neki oblik zastupnikove krivnje.

Čl. 18. (b) propisuje 2 moguća slučaja kada je obvezna odšteta ili naknada, kada sam trgovački zastupnik raskida ugovor. Prvi je uzrok na strani nalogoprimca, ako je on svojim ponašanjem prouzročio raskid ugovora. Drugi uzrok je da se ne može razumno očekivati kako će trgovački zastupnik moći obavljati svoju djelatnost zbog godina, nemoći ili bolesti. Prijevod riječi ,godina“"86 je neadekvatan, jer smisao upućuje na starost trgovačkog zastupnika, utoliko da više nije sposoban obavljati svoju djelatnost. Također, njemačka verzija „,durch Alter“ ili engleska verzija „on

82 Heinicke, Gunther, „Stoplersteine im grenzuberschreitenden Handelsvertreterrecht“, Zeitschrift fur Vetribsrecht, Heft 5., str. 278.

83 Čl. 17. st. 4.

84 Emde, Valdini, opt. cit. str. 11.

85 Čl. 831. ZOO-a.

86 Čl. 18 (b) Direktive: ,... ako je trgovački zastupnik raskinuo ugovor o zastupanju, a ako takav raskid nije opravdan okolnostima koje se mogu pripisati nalogodavcu ili na temelju godina, nemoći ili bolesti trgovačkog zastupnika, zbog čega se od njega ne može razumno zahtijevati da nastavi s djelatnostima..." 
the ground of age" upućuje na takav prijevod. U praksi se ipak treba prosuditi bi li na strani zastupnika bilo moguće uzeti u obzir neke druge uzroke, koji bi u svakom slučaju trebali biti neskrivljeni, iznimni, nepredviđeni i neotklonjivi te bi morali prelaziti poduzetničke rizike. ${ }^{87} \mathrm{ZOO}$ u čl. 831. propisuje mogućnost posebne naknade u slučaju starosti ili bolesti koja sprečava trgovačkog zastupnika da nastavi ugovorni odnos.

Što se tiče trećeg razloga za neplaćanje kompenzacije, smatra se da kod prijenosa ugovora na drugu osobu, također ne može nastati obveza plaćanja odštete ili naknade štete, ako trgovački zastupnik, sporazumno s nalogodavcem, svoja prava i obveze iz ugovora o zastupanju prenese na drugu osobu. ${ }^{88}$

Direktiva propisuje da stranke ne mogu odstupati od čl. 17. i 18. na štetu trgovačkog zastupnika prije isteka ugovora o zastupanju. ${ }^{89}$ Dakle, propisi o posebnoj naknadi i naknadi štete djeluju kogentno s time da je državama članicama omogućen izbor vrste naknade koji će propisati. No, domašaj čl. 19. daleko je širi od materijalnopravnog propisa koji treba vrijediti u zakonodavstvima država članica. Europski sud odlučio je da nije moguće prekludirati pravo na terminalnu naknadu propisivanjem primjene prava države nečlanice u ugovorima između država članica Unije i država nečlanica. ${ }^{90}$ Korak dalje u zaštiti prava trgovačkog zastupnika poduzeo je u odluci Unamar. U pitanju je li izbor bugarskog zakonodavstva, usklađenog s Direktivom, opravdan jer je manje povoljan za trgovačkog zastupnika, Europski je sud presudio u korist povoljnijeg prava. ${ }^{91}$ Njemački Savezni vrhovni sud $(\mathrm{BGH})$ proširio je primjenu čl. 17., 18. i 19. na inozemne distributere. ${ }^{92}$

Zemlje članice bile su dužne donijeti propise koji će osigurati da kompenzacija u svakom slučaju nije manja od onog što propisuje čl. 17. Vezano za iznos kompenzacije, Europski sud odredio je da nacionalno pravo, koje glede izračunavanja iznosa kompenzacije predviđa tarife i sadrži pravila o izračunavanju iznosa, nije dopušteno. ${ }^{93}$ Osim toga, Direktiva ne daje nikakve konkretnije upute na temelju kojih faktora treba izračunati visinu naknade.

Vezano za treći slučaj, kada se ne može propisati obveza plaćanja naknade štete ili odštete (ako u sporazumu s nalogodavcem zastupnik ustupi svoja prava i obveze iz ugovora drugoj osobi), polazi se od pretpostavke da je u trenutku ustupa ugovora trgovački zastupnik bio dovoljno kompenziran, te je stoga prekludiran od daljnjih potraživanja od nalogodavca.

\footnotetext{
Kordiš, opt. cit. u bilj. 66.

Čl. 18. (c) Direktive.

Čl. 19. Direktive.

Presuda Ingmar, vidi potpoglavlje 7.1.

Presuda Unamar, vidi potpoglavlje 7.1.

Emde, Valdini, opt. cit., str. 12.

Presuda Honyvem, vidi potpoglavlje 7.11.
} 


\subsection{Klauzula zabrane obavljanja djelatnosti / konkurencije}

Obveza nekonkurencije prvotno se odnosila na obvezu trgovačkog zastupnika da ne stupa u poslovne odnose koji bi mogli konkurirati nalogodavcu. ${ }^{94}$ Pravna osnova takve obveze nalazi se u primjeni načela savjesnosti i poštenja u ugovorima o trgovačkom zastupanju te propisima o nelojalnoj tržišnoj praksi. ${ }^{95} \mathrm{U}$ Direktivi se dispozitivno propisuje mogućnost sklapanja sporazuma kojim se ograničavaju poslovne djelatnosti trgovačkog zastupnika nakon raskida ugovora prema čl. 20. Takva mogućnost naziva se klauzulom zabrane konkurencije te će biti valjana samo ako je zaključena u pisanom obliku te ako se odnosi na zemljopisno područje ili na grupu ili vrstu klijenata ili vrstu robe koju je pokrivalo ugovorno zastupanje (st. 2.). Dakle, klauzula mora biti ograničena konkretno, te se propisuje da je valjana najdulje dvije godine nakon prestanka ugovora. Zadnji stavak omogućuje državama članicama da propišu i druga ograničenja valjanosti ili primjenjivosti zabrane konkurencije ili da sudovi država članica smanje obveze stranaka, koji proizlaze iz obveze nekonkurencije. Tako su primjerice pojedine države članice propisale rok valjanosti klauzule na godinu dana ili su vezale obvezu propisivanja tzv. odštete za vrijeme čekanja (njem. Karenzentschädigung), uz ugovaranje klauzule. ${ }^{96}$

Hrvatski ZOO propisuje detaljno zabranu i ograničenje obavljanja djelatnosti. ${ }^{97}$ Trgovački zastupnik i nalogodavac mogu pisano ugovoriti da zastupnik nakon prestanka ugovora neće smjeti obavljati, u potpunosti ili djelomično, djelatnost trgovačkog zastupanja na istom području, iste osobe ili iste robe na koje se odnosi i ugovor o trgovačkom zastupanju. Ako ugovor prestane zbog razloga koji su na strani nalogodavca, zastupnik će biti obvezan glede te ugovorne obveze samo ako mu nalogodavac po prestanku ugovora plati posebnu naknadu i ako mu u razdoblju trajanja zabrane ili ograničenja obavljanja djelatnosti plaća dodatnu mjesečnu naknadu. Ugovorna odredba o zabrani ili ograničenju obavljanja djelatnosti može obvezivati trgovačkog zastupnika najduže dvije godine nakon prestanka ugovora. Također, ako zastupnik raskida ugovor zbog skrivljenog ponašanja nalogodavca, može u roku od mjesec dana od dana raskida ugovora pisanom izjavom priopćiti nalogodavcu da neće poštovati odredbu o zabrani ili ograničenju obavljanja djelatnosti. ${ }^{98}$

94 Kordiš, Hrvoje, opt. cit. u bilj. 66, str. 17.

95 Posebni propisi o nedopuštenom tržišnom natjecanju doneseni su primjerice u Njemačkoj, Austriji i Švicarskoj pod nazivom ,unerlauterter Wettbewerb“.

96 Mayer, J., op. cit. u bilj. 4, str. 457.

97 Čl. 834. ZOO-a.

98 Slično je propisano i u njemačkom $\S 90 \mathrm{a}$, s time da je nalogodavcu dana mogućnost odricanja od tog ugovornog propisa, ali s obvezom plaćanja odštete u trajanju od 6 mjeseci nakon dana notifikacije trg. zastupniku da odustaje od ugovorene obveze. 


\section{ANALOGNA PRIMJENA}

Kao što je već spomenuto, pojedine države članice proširile su primjenu Direktive na ostale slične ugovore koji sadržajno imaju mogućnost da se na njih primijeni Direktiva, na primjer na trajne ugovore o komisiji. ${ }^{99}$ U pojedinim državama članicama Direktiva je implementirana tako da se primjenjuje i na trgovačke putnike.

Nameće se pitanje kada je i u kom obimu moguće proširiti primjenu Direktive na ostale slične trgovačke ugovore. Tako se na primjer u Njemačkoj zakonodavac odlučio, a i sudska praksa je potvrdila takvu primjenu, da se Direktiva može primjenjivati na ugovore o komisiji, posredovanju i franšizi. U ostalim državama članicama također se primjenjuje takva analogija, i to osobito kod zahtjeva za naknadu trgovačkog zastupnika ${ }^{100}$ te se ponegdje opravdava i u presudama visokih sudova država članica. ${ }^{101}$

No, Europski sud ne primjenjuje Direktivu analogno, ustručavajući se na taj način harmonizirati pravo i praksu država članica u područjima koje Direktiva nije izravno propisala. ${ }^{102}$ Usprkos tome, u svojoj praksi priznaje široku implementaciju Direktive državama članicama te praksu nacionalnih sudova da analogno primjenjuju značenje direktive. Također, priznaje i prethodna pitanja koja su proizašla iz takve opširne primjene Direktive, ako se odnose na pojmove definirane u Direktivi. ${ }^{103}$

Tako se na primjer Europski sud u presudama „Poseidon chatering“ i „Unamar“ bavi provizijama iz područja usluga transporta, koje su regulirane nizozemskim i belgijskim trgovačkim pravom, ${ }^{104}$ dok se presuda „Volvo Car Germany“ dotiče njemačkog ugovora o distribuciji. Na taj način Direktiva kroz praksu Europskog suda zapravo djeluje preko granica svog pretpostavljenog djelovanja te zadire i $\mathrm{u}$ ostala područja trgovačkog prava Europske unije i prava država članica.

\section{POSTIGNUTA HARMONIZACIJA}

Provedba čl. 17., 18. i 19. u zakonodavstvu država članica nije prošla bez poteškoća, zato što su države članice na različite načine implementirale Direktivu u svoja zakonodavstva. ${ }^{105}$ Većina ${ }^{106}$ se odlučila na model posebne naknade koja se u svakoj od država računa na drugi način, slijedeći naravno osnovne pretpostavke Direktive ${ }^{107} \mathrm{U}$ Italiji se također primjenjuje model posebne naknade, koji se u praksi

99 Mayer, J., op. cit. u bilj. 4, str. 448.

100 Čl. 17. Direktive.

101 Emde, Raimond, "BB-Rechtsprechungsreport Zum Vertriebsrecht 2016", Betriebs-Berater, 50 (2017), str. 2949

102 Mayer, J., opt. cit., str. 448.

103 Vidljivo prema presudama Europskog suda od presude Leur-Bloem te osobito u presudi Mavrona.

104 Vidi presude Poseidon i Unamar.

105 Saenger, Ingo, op. cit. u bilj. 4, str. 9.-16.

106 Na primjer Njemačka, Austrija i Nizozemska.

107 Mayer, J., op. cit. u bilj. 4, str. 456. 
određuje sustavom tarifa propisanih kolektivnim ugovorima. ${ }^{108}$ Nasuprot tome, Francuska i Irska prihvaćaju sustav naknade štete, s time da se u francuskoj sudskoj praksi iznos odmjerava u visini dviju godišnjih provizija. ${ }^{109}$ Engleski zakon također se temelji na modelu naknade štete, ali dopušta i pravo trgovačkog zastupnika na posebnu naknadu. ${ }^{110}$

Hrvatski zakonodavac opredijelio se za model posebne naknade, kao što je vidljivo iz čl. 830. - 833. koji slijede više-manje iste formulacije kao i čl. 17. st. 2.

Osim navedenih problema uvođenja prava odštete radi raskida ugovora, postignuto usklađivanje prava trgovačkih zastupnika u zemljama članicama nije cjelovito zbog ograničenosti zakonske definicije čl. 17. st. 2. te u njemu predviđenog načela pravičnosti. ${ }^{111}$ Smjernice Komisije iz 1996. godine preporučuju usmjerenje prema njemačkom zakonu (HGB). ${ }^{12}$ Usprkos tomu, u usporedbi sa situacijom prije 1986. godine ne postoji nikakav razlog da se pripišu ikakvi negativni učinci Direktivi. ${ }^{113}$

\section{REFIT}

Europska komisija ispitala je Direktivu u okviru Programa za prikladnost i učinkovitost propisa. REFIT ${ }^{114}$ je dio programa Komisije kojim se propituju uspješnost, učinkovitost i troškovi primjene za građane i poduzeća zakonodavstva EU-a. REFIT-om se nastoji pojednostavniti zakone Unije i prilagoditi ih postojećem zakonodavstvu, stvarnom stanju te smanjiti birokraciju.

Tako su 2014. godine provedene konzultacije s granskim udrugama koje su ocijenile da Direktiva ispunjava svoj cilj u svakom pogledu. No, postoji i mišljenje da bi za očuvanje i napredak u razvoju prava trgovačkih agenata bilo učinkovitije donijeti Uredbu po uzoru na Prijedlog uredbe o zajedničkom europskom kupoprodajnom pravu. ${ }^{115}$

U nastavku se obrađuje izvješće programa REFIT prema obrađenim aspektima ocjene Direktive. Pri ocjeni Direktive željelo se utvrditi je li Direktiva i dalje važna zainteresiranim strankama i posjeduje li tzv. „dodatnu vrijednost za EU“.

Prema početnim ciljevima uklanjanja distorzija i harmonizacije prava trgovačkih agenata s ciljem zaštite prava trgovačkih agenata, brzo se ustanovilo da je Direktiva

108 Saenger, Ingo, opt. cit., str. 143.

109 Mayer, J., op. cit. u bilj. 4, str. 456.

110 Saenger, Ingo, opt. cit., str. 103. i 105.

111 Mayer, J., op. cit. u bilj. 4, str. 456.

112 Anwendungsbericht Kom (1996.) 364, str. 2.

113 Mayer, J., op. cit. u bilj. 4, str. 456.

114 Regulatory Fitness and Performance Programme.

115 Martinek, Michael, „Neue Perspektiven zur Europäisierung des Handelsvertreterrechts“, Zeitschrift für Vertriebsrecht, 2014., str. 139. 
postigla navedene ciljeve. ${ }^{116}$ Direktiva je zaštitila prava trgovačkih agenata koja u mnogim državama članicama prije nisu bila zaštićena. Povijesno gledano, države članice imale su različito zakonodavstvo glede prava i obveza trgovačkih zastupnika i njegovih nalogodavaca. Smatra se da je to stvaralo pravne nesigurnosti i poteškoće u funkcioniranju zajedničkog tržišta Europske unije. Zbog toga se 1986. godine donijela Direktiva čiji je cilj bio stvaranje zajedničkog tržišta za trgovačke zastupnike i otklanjanje prepreka u međunarodnoj pripadnosti trgovačkih agenata i njihovih nalogodavaca. Konkretnije, Direktiva harmonizira pravila država članica o: pravima i obvezama trgovačkih agenata i njihovih nalogodavaca, o naknadi, o zaključivanju i o raskidu ugovora, osobito u pogledu kompenzacije odnosno naknade štete koja se duguje trgovačkom zastupniku vezano za okončanje ugovora.

Evaluacija Direktive u okviru programa REFIT trebala je ocijeniti jesu li ostvareni njezini prvotni ciljevi te može li se još uvijek učinkovito primjenjivati. Evaluacijski kriteriji bili su sljedeći: a) uspješnost, b) učinkovitost, c) relevantnost, d) dodana vrijednost za EU i e) koherentnost s ostalim propisima EU-a.

Izvješće navodi kako je bilo teško pronaći pouzdane ekonomske podatke koji bi podupirali analizu navedenih kriterija. Statistika i kvantificirani podaci o djelatnosti trgovačkih agenata prije i poslije uvođenja Direktive ne postoje, zato što su Eurostatovi podaci za trgovačke djelatnosti dostupni tek od 2008. godine. Zato je bilo teško provesti stvarnu kvantificiranu analizu te uspostaviti stvarnu analizu troškova i koristi djelovanja Direktive. S obzirom na to da nema pouzdanih podataka o učincima Direktive, primijenila se metoda javnog savjetovanja, koja se ponajprije usredotočila na zainteresirane stranke i pojedine organe država članica. Konzultacijama se željela dokazati funkcionalnost Direktive i njezina dodana vrijednost za zajedničko tržište Unije te ocijeniti njezina budućnost u zakonodavstvu EU-a i zakonodavstvu država članica. Koristili su se i Eurostatovi podaci i informacije predstavnika trgovačkih asocijacija i akademske zajednice.

Nakon provedene analize, pokazalo se da je Direktiva u pogledu uspješnosti ispunila svoje ciljeve pri ostvarivanju međunarodnih aktivnosti. Dalekosežni ekonomski podaci koji mogu poduprijeti ovaj zaključak dostupni su samo za dvije države - za Njemačku i Austriju. No, konzultacije sa zainteresiranim strankama i državama članicama pokazale su da postoji konsenzus da Direktiva uspješno funkcionira u zadanim okvirima. Zato što ne postoje opsežni kvantitativni podaci prije i poslije uvođenja Direktive, analiza učinkovitosti počiva uglavnom na kvalitativnim podacima. Na temelju tih podataka pokazalo se da su troškovi koje je donijela primjena Direktive prihvatljivi i ograničeni. Dok sama Direktiva zapravo ne stvara administrativne troškove, moguće je bilo da stvaranje inkrementalnih operativnih troškova za nalogodavce u državama koje nisu prije regulirale djelatnost trgovačkog zastupanja (npr. Ujedinjeno Kraljevstvo, Irska i Švedska). Direktiva je pridonijela stvaranju značajnih operativnih i trgovinskih koristi, olakšavajući međunarodno poslovanje. Analiza troškova i koristi na razini individualnog poslovanja pokazala je da koristi nadmašuju troškove. Što se tiče relevantnosti, pokazalo se da je važnost

116 Mayer, J., op. cit. u bilj. 4, str. 457. 
Direktive i danas aktualna za održavanje trgovačke djelatnosti, osobito za mala do srednja poduzeća (SME). Dodana vrijednost za EU također je dokazana, zbog razine harmonizacije do koje dovodi implementacija Direktive u zakonodavstvo država članica. Pokazalo se da i potrošači uživaju pogodnosti od stvorenog okvira, jer im se omogućuje pristup dobrima koja inače ne bi bila dostupna u njihovim zemljama.

U konzultacijama s trgovačkim zastupnicima i drugim zainteresiranim strankama zaključilo se da je djelatnost trgovačkog zastupanja osigurana samo ako se Direktiva nastavi primjenjivati, jer se smatra da bi se u suprotnom fragmentirala prava država članica, što bi otežalo djelatnosti međunarodnoga trgovačkog zastupanja.

U zaključku REFIT-a ocjenjuje se da nije pronađen niti jedan sukob s ostalim politikama zakonodavstva EU-a te da Direktiva podupire politiku Europske komisije o razvoju malog i srednjeg poduzetništva.

\section{ZAKLJUČAK}

Direktiva o usklađivanju prava država članica EU-a u vezi sa samozaposlenim trgovačkim zastupnicima (86/653/EEZ) donesena je 1986. godine kako bi se uskladila nacionalna zakonodavstva država članica kojima se reguliraju ugovori između samozaposlenih trgovačkih zastupnika i njihovih nalogodavaca. S obzirom na to da se radi o pravnom uređivanju putem direktiva, svaka pojedina zemlja mogla je odabrati način kako će implementirati propise ove Direktive u svoje zakonodavstvo. Hrvatsko zakonodavstvo odlučilo je da će se Direktiva primjenjivati samo u reguliranju ugovora o trgovačkom zastupanju u Zakonu o obveznim odnosima. Pojedine države članice proširile su primjenu Direktive na ostale slične ugovore koji sadržajno imaju mogućnost da se na njih primijeni Direktiva.

Budući da je postojala značajna razlika u nacionalnim pravima država članica, koja je utjecala na uvjete tržišnog natjecanja i zastupanja u Uniji, od šezdesetih godina 20. stoljeća unutar zakonodavstva Europske ekonomske zajednice postojala je tendencija za donošenjem zakonodavstvenog okvira za zaštitu trgovačkih zastupnika.

Opći cilj Direktive bio je stvaranje jedinstvenog tržišta za trgovačko zastupanje i uklanjanje prekograničnih aktivnosti trgovačkih zastupnika i njihovih nalogodavaca. Direktiva usklađuje: prava i obveze trgovačkih zastupnika i njihovih nalogodavaca, naknade trgovačkim zastupnicima te osobito odštete ili naknade trgovačkim zastupnicima nakon završetka ugovora. Glavni razlog donošenja bili su nastojanje na poboljšavanju uvjeta tržišnog natjecanja unutar Europske unije, povećanje sigurnosti trgovačkih poslova te uredno poslovanje na zajedničkom tržištu.

Ukratko, Direktiva uređuje prava i obveze nalogodavaca i njihovih trgovačkih zastupnika, naknadu trgovačkim zastupnicima te zaključivanje i prestanak ugovora uključujući naknadu štete koja pritom može nastati.

Europski sud pravde razvija praksu vezanu za Direktivu na način da sud ne primjenjuje Direktivu analogno, čime se de facto ustručava harmonizirati pravo i 
praksu država članica u područjima koje Direktiva nije izravno propisala. Međutim, u svojoj praksi priznaje široku implementaciju Direktive državama članicama te praksu nacionalnih sudova da analogno primjenjuju značenje Direktive. Također, priznaje i prethodna pitanja koja su proizašla iz takve opširne primjene Direktive, ako se odnose na pojmove definirane u Direktivi. Tako je u važnoj presudi Ingmar odlučio da je - s obzirom na to kako je trgovački zastupnik djelovao na području Europske unije te usprkos činjenici kako je u ugovoru propisana primjena nacionalnog prava države nalogodavca - potrebno zaštititi pravo na naknadu trgovačkog zastupnika kako je propisano Direktivom. Međutim, još uvijek ostaje otvoreno trebaju li se svi kogentni propisi, koje nameće Direktiva u tom smislu, primjenjivati i na međunarodno procesno pravo te do koje mjere, a i koji ostali faktori mogu utjecati na izravnu primjenu Direktive.

Europska komisija je u prosincu 2012. u svom programu REFIT, koji je uspostavljen radi učinkovitijeg provođenja europskog zakonodavstva, preispitala i Direktivu o usklađivanju prava država članica u vezi sa samozaposlenim trgovačkim zastupnicima. Pokazalo se da je Direktiva postigla željene ciljeve u zaštiti prava trgovačkih zastupnika te da je pridonijela harmonizaciji prava država članica. U mnogim zemljama dovela je do uspostavljanja takvog vida zaštite trgovačkih zastupnika koji prije nije postojao u zakonodavstvu.

\section{DIRECTIVE ON THE HARMONIZATION OF THE RIGHTS OF EU MEMBER STATES WITH REGARD TO SELF- EMPLOYED COMMERCIAL AGENTS}

The Directive on the harmonization of the rights of EU Member States with regard to selfemployed commercial agents entered into force in 1986 with the aim of harmonizing the legislation of the EU Member States on contracts between self-employed commercial agents. The Directive harmonizes: the rights and obligations of commercial agents and their principals, compensation of commercial agents and, in particular, compensation or compensation of commercial agents after the end of the contract. The objectives of the Directive are the protection of commercial agents, the improvement of conditions of competition within the European Union, the increase of the security of commercial operations and the orderly operation of the common market. As part of the REFIT program in 2012, the European Commission assessed the Directive as successful and efficient, which is important since the activity of trade representatives accounted for 3 percent of trade turnover in the Union.

Key words: Directive on self-employed commercial agents, European law, Commercial law 